\title{
Working Capital Management and Firm Performance: An Empirical Study for Malaysian Public Listed Companies in Property Industry
}

\author{
Sim Siew Ling*, Azlan Ali, and Winnie Wong Poh Ming \\ School of Business and Management \\ University College of Technology Sarawak, \\ No. 1, Jalan Universiti, 96000 Sibu, \\ Sarawak, Malaysia. \\ Corresponding author: simsiewling@ucts.edu.my
}

\begin{abstract}
Over the erstwhile two decades, complexity and dynamism of the business environment have postulated greater devotion of treasurer to possess meticulously comprehension on the principal driving forces for the firm's performance. Working capital management is a compelling managerial decision-making in attaining the exemplary which counterbalances between short-term risk and return. This study contemplates furnishing certain intuition for the appositeness of contemporaneous literature as regards the effectiveness of managing short-term resources towards the firm's performance. This study adopts dynamic panel data methodology, generalised method of moments (GMM) to capture for the unobserved time-invariant firm-specific elements. Using a sample of 72 Malaysian public companies listed on Bursa Malaysia in property economy sector from years 2007 through 2016, the researcher discovered evidence as follows: the coefficient findings implying insignificant negative linkage between working capital components (i.e. CCC) and firm performance indicators (Tobin's Q) and the nonconformity of results as comparable with prior established literature from developed nations due to the divergent of business environment as well as the adoption of different methodology to test the model.
\end{abstract}

Keywords: Firm Performance, Generalised Method of Moments GMM); Plantation Industry; Working Capital Management (WCM)

\section{Introduction}

The precedent literature has been enlightening that the corporate finance have conventionally put greater emphasize on long-term financial decisions such as investments, capital structure, dividends and corporate valuations decisions (Almeida \& Eid, 2014), as corroborated by the meagre enlightenment of underlying theories which have given precedence to sufficiently elucidating the interlinkage between working capital management and firm performance (Palombini \& Nakamura, 2011). Correspondingly it propels the negligence of finance managers on the pertinence of having effective management of short-term assets and liabilities (Ukaegbu, 2014; Zariyawati, Annuar, Taufiq, \& Abdul Rahim, 2009), in particular while dealing with corporate financial planning and controlling tasks (Kwenda \& Holden, 2014; Pass \& 
Pike, 1984), by providing reasoning of short-term decision-making is generally performed in the recurring basis which seemed as may possibly reversible over time in case of erroneous judgment occurs (Singh \& Kumar, 2014). Inevitably, the decisions made concerning the utilisation of short-term resources would impinge on the firms' long-term strategic development, in place of management of short-term financial resources has a direct influence on firms' operations (e.g. supply chain management), from the perspective of cost structure as well as ability of future earnings (Motlíček \& Polák, 2015). The significance of working capital management is noteworthy irrespective of the firms' size, sector, industry, country as well as the nature of economy (Bhatia \& Srivastava, 2016).

Working capital management (hereafter WCM) is a forcible managerial judgment in pursuing the paradigmatic whereby counterbalance between risk and return. The preceding empirical findings have affirmed that the working capital as one of the most influential yet least comprehends drivers for supply chain managers (Losbichler \& Mahmoodi, 2012), with the steering to improve a firm's cash flow and profitability (Deloof, 2003). Working capital efficiency has come the light during the prior decades as the distortion of business environment, likewise shifting the conventional focal point of scholars and practitioners on market efficiency (Sartoris \& Hill, 1983) towards generating greater returns by optimizing working capital. Adjacent to the shifting of paradigm in which attributable to the turbulent financial markets as well as the escalating risks on the global commodity market has forsaken the finance manager with diminutive chance to linger with their traditional practices. Conforming to PWC Global Working Capital Opportunity report (PWC, 2017), working capital performance has progressively impaired over the past ten years as a result that the deficiency of management attention on cash management. Corresponding to the findings of CFO Innovation, the firms in the United Kingdom were discovered of placing a low priority in managing their liquidity risk as the finance managers were lacking comprehension as regards the degree of uncertainties while dealing with both investment and financing matters.

Mounting devotions has been placed on WC efficiency for the preceding two decades (Lyroudi \& Lazaridis, 2000), notably henceforth the sub-prime crisis in the year 2007. WCM has turn out to be more prominent particularly in the challenging current business environment which as well as hiking of costs of operations, stringent terms and conditions imposed by financial institutions (Padachi \& Howorth, 2014), as well as erstwhile evidences affirming that current assets are constituted of a significant fraction of total assets owned by the firms (Bhatia \& Srivastava, 2016). In the Malaysian context, the exiguous of preceding investigations pertaining to the affiliation of WCM on firms' performance (Darun, Roudaki, \& Radford, 2015; Wasiuzzaman, 2015). Extensive of international empirical researches have been progressively pondered the interaction of short-term financial management in order to theorise the interconnection with firm's performance. Nonetheless, the apprehension of WCM efficiency among public listed companies in Malaysia is not as explicitly cognizant as comparing with other Western territories, as given with the exposition that divergence of the disposition of business environment setting (Darun et al., 2015). 
Malaysia, as a developing nation with evolving financial market infrastructure ought to be placed greater attention with working capital efficiency as prior literature has accentuated that corporations in Malaysia were not accomplishing satisfactory working capital performance (Wasiuzzaman, 2015). The rationale to select property economy sector was due to its experiences of boom period during years 2006-2018, with the peak interval took place in years 2011 and 2012, on the grounds of gaining desirable expected returns arisen from the investment and supportive monetary policies set by the government (Ferlito, 2018). Thence, this study attempts to augment contemporary deficient of literature through supplement the latest empirical findings to the extent of which re-examining the interrelation between WCM and corporate performance.

\section{Literature Review}

Working capital is being defined as current assets (i.e. accounts receivable, inventories, cash and short-term marketable securities) minus current liabilities (i.e. accounts payable, bank overdrafts, other short-term loans and outstanding tax, dividend and interest obligations) in which is known as net current assets (Pass \& Pike, 1984). As exemplifying as a routine function which is predispose management decision on the firm's effectiveness in utilizing resources (Kaur, 2010), thence working capital management has been deliberated as one of the influential indicators for a firm's shortterm financial position (e.g. customer receipts and payment to suppliers), wherein it's imperative for the attainment of two-fold objectives, liquidity and profitability of the firm (Smith, 1987). Additionally, net working capital is contemplated as a measurement of operating liquidity in which inefficient working capital management and planning may possibly hinder the competitiveness advantages (Eljelly, 2004), whereas giving rise to the problems such as overcapitalization i.e. disproportionate of working capital which results in extensive investment in fixed assets meanwhile overtrading i.e. exaggerated sales volume lead to incommensurate non-current assets in supporting the business operations.

The empirical researches have supported the postulation stating that firms ought striving for an optimal level of working capital components which are receivables, inventory, payables and cash, with the postulation to maximise the shareholders' wealth (Afrifa \& Padachi, 2016; Nazir \& Afza, 2009; Deloof, 2003). The efficiency of working capital management links with releasing cash tied up from inventories and accounts receivable whereas pertaining to the antecedent of accelerating the collection of receivables in the shortest duration as possible on top of delaying disbursements to suppliers in the feasible yet lengthiest period (Nobanee, Abdullatif, \& AlHajjar, 2011). Effective working capital policy manages to boost corporate performance through shortening the CCC period, consequently creating incremental firm value (BañosCaballero, García-Teruel, \& Martínez-Solano, 2014).

The dispute of working capital management has been undergoing an extensive researches which converging the addressing on the trade-off either upholding positive working capital (Gill, Biger, \& Mathur, 2010) or negative working capital (Wasiuzzaman, 2015; Mansoori \& Muhammad, 2012; Zariyawati et al., 2009; Garcia- 
Teruel \& Martinez-Solano, 2007; Raheman \& Nasr, 2007; Eljelly, 2004) would enhance firm's performance. In conjunction with the expostulation, it could profoundly scrutinise the financial implications between firms that possessing a substantial amount of working capital (i.e. large inventory and less stringent trade credit policy) and those having minimal working capital level (i.e. lowest possible inventory level and strict trade credit policy). In light of a high working capital investment, the firms might have to bear unnecessary inventory holding costs (Deloof, 2003), likewise increase the bad debt risk which would engender negative impact on firms' profitability (Gill et al., 2010). Contrarily, low level of working capital might trigger loss of sales due to inadequate supplies as well diminishing the competitive edge as customers might switch to other traders whereby Ross, Westerfield, and Jordan (2010) denotes it as the opportunity cost of margin i.e. the loss results from unable to offer acceptable credit terms.

The WC proxy has been deriving from the development of various models used in measuring short-term operational efficiencies, starting with cash conversion cycle (here onwards, CCC) (Richards \& Laughlin, 1980); net trade cycle (Shin \& Soenen, 1998); and weighted CCC (Gentry, Vaidyanathan, \& Lee, 1990). Yet, CCC has been reckoned as a powerful as well as an appurtenant proxy for WCM for estimating the liquidity position of a firm (Jose, Lancaster, \& Stevens, 1996). The definition of CCC appears to be inconsistent (Nobanee et al., 2011), whereby Steward (1995) delineates CCC as a combined measurement illustrating the average period of time required to convert a dollar invests in purchasing raw materials into a dollar collected from credit customers.

\section{Components of Working Capital Management (WCM) \\ Inventories}

Ostensibly, it's prominence for firms to meritoriously invest in their short-term assets (i.e. inventories and receivables) as it regards a force that stimulating firm's sales growth, which counterbalances with the argument of Moss and Stine (1993) which avowing that investment in the long-term assets could be diminishing throughout the time horizon as alternatively, firms may possibly have alternatives either to rent or lease the assets. The availability of inventories is crucial for businesses' operations and greatly affected by the level of sales and accounts receivable. The assorted composition of inventories has prominent weight in influencing firms' WCM efficiency due to its direct interconnection with the trade-off of firms' profitability and liquidity (Raheman \& Nasr, 2007). Thereupon, trading-off between holding costs and opportunity costs transpires while making decisions whether to undertake the settlement discounts offered by the suppliers (Nobanee et al., 2011). The previous empirical studies have predominantly established the negative results of DIO towards firms' performance (Bhatia \& Srivastava, 2016; Lyngstadass \& Berg, 2016; Mansoori \& Muhammad, 2012; Zariyawati et al., 2009; Raheman \& Nasr, 2007). An aggressive strategy of WCM will result in the reductions in inventory holding (Baños-Caballero et al., 2014) that resultant in the improvement of firm's performance remarkably on the accounting performance measurements due to the rationale of minimization of inventory-holding costs which comprising of warehouse storage costs, insurance premium expenses, cost of spoilage and theft of inventory 
(Deloof, 2003). Contrastively, there are studies which demonstrate positive relationship between DIO and firm profitability (Makori \& Jagongo, 2013; Mathuva, 2010), by means of higher levels of inventories are presumed to increment in sales and reducing transaction costs simultaneously (i.e. bulk purchase discount, reduce ordering costs, minimizing loss of sales etc.). The inconsistent ramification on the significance of DIO towards firm's performance has stimulate the researcher to delve further specifically for corporations deriving from diverse industries.

\section{Account Payables}

Trade credit plays a substantial role to finance business short term operational liabilities (Petersen \& Rajan, 1997) in which it allows the firms to enjoy the interest-free source of capital whereas granting the firms to invest their surplus cash for additional returns (Tauringana \& Afrifa, 2013). A properly planned and executed payable management could contribute positively to the expansion of firms' activities, consequently boosting sales revenue (Madishetti \& Kibona, 2013) which enabling the firms to ameliorate the regeneration of funds and further generating a higher level of profitability. Conventionally, cash constrained firms incline to substitute trade credit to borrowings of financial institutions as it diminishes the purchasing costs particularly during the tightening monetary supply periods (Atanasova, 2008), by means of having adequate time duration to ascertain the quality of products before making the payment to the suppliers (Petersen \& Rajan, 1997). The inversed relationship amid days of payables outstanding (DPO) and firms' performance has been induced as the rationale of the excessively delaying the payments to suppliers (Bhatia \& Srivastava, 2016; Lyngstadaas \& Berg, 2016; Mansoori \& Muhammad, 2012). Nonetheless, it might cause a certain deteriorating effect on firms' creditworthiness, and therefore negatively affect profitability as the purchasing cost could escalate (Nobanee et al., 2011). Hitherto, several empirical investigations have signified the positive interconnection between DPO and firm performance (Makori \& Jagongo, 2013; Mathuva, 2010; Raheman \& Nasr, 2007). Thereupon, the discrepancy of previous outcomes has provoked the captivation to further examine the significance of the length of DPO in influencing firm performance.

\section{Firm Performance}

In term of dependent variables i.e. firm performance, the first DV is return on assets (ROA) which has been widely adopted as an accounting based measurement that uses to indicate the how efficient the firms in generating profits by utilizing its resources (Baños-Caballero et al., 2014; Makori \& Jagongo, 2013; Garcia-Teruel \& MartinezSolano, 2007; Nazir \& Afza, 2009; Zariyawati et al., 2009). The exposition of ratifying ROA is considering its ability to measure the accomplishment of management pertaining to the specific amount of resource, withal the indicator removes the firm size effect which allowing for inter-industry comparison (Tauringana \& Afrifa, 2013). The second dependent variable, Tobin's q is a market-based gauge wherein viewing as a reliable indicator (Baños-Caballero et al, 2014) in alleviating most of the flaws inherent as comparable to accounting profit ratios, in view of accounting policies incline to affect the sensibility of the results of the ratios as well as capital market valuation particularly 
when comes to the incorporation of business risks, on top of the reduction of possible distortions of newly implemented tax system and accounting conventions (Gilligan, Smirlock, \& Marshall, 1984). The hypothesis of the interrelation between CCC and firm performance indicators is listed as below:

Hypothesis: The CCC will have a negative significant relationship on firm performance for the property sector.

\section{Research Methodology}

\section{Data filtration and sample selection}

In the context of this study, a cross-sectional study involves Malaysian public-listed companies that and longitudinal study is lasting for 10 years which comprising from the period of financial year 2007 to financial year 2016. The data needed for empirical testing of the research hypotheses is collected from the secondary data of the audited financial statement of firms listed on the main market of Bursa Malaysia and Morningstar Incorporation. Acknowledging the fact that it is challenging to collect data from SMEs, therefore the research scope is public listed firms which generally largerscale firms. Afrifa (2013) concedes that SMEs are unwilling to reveal information due to the concern of the disclosure might make known to its competitors. Morningstar Inc. is an independent investment research provider that furnishes both the quantitative and non-financial data and information about a firm's performance, for instance, ratios analysis, shareholding analysis, stock performance, valuation, announcement, analysis of financial statement and etc. Kamal (2013) treated Morningstar as one of the useful and unbiased sources of information in order to assist investors to make their investment decision. The secondary data is derived from annual reports published on Bursa Malaysia website, which is deemed as a reliable yet extensive source of information, concerning pecuniary as well as submission of the reports or announcements to keep investors and the public fully informed of all facts and information in the approach of full, accurate and timely disclosure (Bursa Malaysia, 2019). The firms that are operating in banking and finance, insurance, mutual funds, and business services are excluded from the selection of sample due to the specific nature of business (Mansoori \& Muhammad, 2012), different accounting requirements (Deloof, 2003) and greater legal scrutinise of working capital practices has been imposed on the specified sector (Bandara, 2015). Subsequently, the data filtration takes into account of selection criteria such as consistent financial month ended for the fitted time frame of ten years (i.e. 2007 - 2016), absence of abnormal financial figures i.e. negative shareholder equity amount, and without missing numbers for data file compilation.

\section{Research Model and Measurement}

The researcher intends to test the hypothesis as regards the influence of working capital management on firm performance, through dynamic panel data which is defined as the pooling of observations on a cross-section of studies objects i.e. public listed companies (PLCs) throughout several time periods (Baltagi, 2005). Panel data analysis which has 
extensively being adopted in past studies for data estimation and modelling as the following benefits: (i) it permits researchers to control for unobservable firm-specific or time-invariant variables that could remove the hazard of biased verdicts which may arise from the heterogeneous firm explicit features that might influence their valuation due to its complexity in estimation or difficulty to access the data; (ii) it improves the efficiency of the econometrics estimations by taking into consideration individual differences between cross sections as well as the time differences between the periods inclusive dummy variables (Hsiao, 2003). Dynamic panel estimators are constructed with the following proviso: (i) small $\mathrm{T}$, large $\mathrm{N}$ panels, indicating small number of time periods and large number of cross-section units; (ii) a linear functional relationship; (iii) one dependent variable that is dynamic, depend upon its peculiar prior accomplishment; (iv) independent variables are permitted not be strictly exogenous, signifying explanatory variables are conceded to be correlated with elapsed and plausibly recent realizations of the errors; (v) fixed individual effects; and (vi) heteroscedasticity and autocorrelation within individuals but not across them (Roodman, 2009). Dynamic panel data allows for one left-hand-side variables to be dynamic i.e. relying on its own historical realizations, whereby y is not required to be strictly exogenous, i.e. y could correlated with past and likely present realization of the errors. In addition, dynamic panel estimators permit heteroskedascity and autocorrelation within individuals, however not across them (Roodman, 2009). The researcher therefore gauges the model using the one-step generalised method of moments (GMM) estimator (Arellano \& Bond, 1991), whereby it permits the controlling of endogeneity problem by inserting instrumental variables.

\section{Research Model Specification}

The delineation of operational definitions for variables has been illustrated in Table 1 .

\section{Table 1 Summary of Variables Calculation}

\begin{tabular}{|c|c|}
\hline Variables & Formula/Definition \\
\hline \multicolumn{2}{|l|}{ Independent Variables } \\
\hline $\begin{array}{l}\text { Cash conversion cycle } \\
{[\mathrm{CCC}]}\end{array}$ & $\begin{array}{l}\text { Days of Inventories outstanding + Days of sales outstanding - } \\
\text { Days of payables outstanding }\end{array}$ \\
\hline \multicolumn{2}{|l|}{ Dependent Variable } \\
\hline Return on assets [ROA] & Profit before interest and tax $\div$ Total assets \\
\hline Tobin's Q [TOBINSQ] & (Market capitalisation + Total debts) / Total assets \\
\hline \multicolumn{2}{|l|}{ Controlled Variables } \\
\hline Firm Size [SIZE] & $\begin{array}{l}\text { The natural logarithm of the firm total assets at the end of the } \\
\text { financial year }\end{array}$ \\
\hline Sales Growth [SALES] & Sales $_{t}-$ Sales $_{t-1} /$ Sales $_{t-1}$ \\
\hline Financial Leverage [LEV] & Total Assets $\div$ Total Shareholders' equity \\
\hline Current asset ratio [CATA] & Current assets $\div$ Total assets \\
\hline Current liabilities ratio [CLTA] & Current liabilities $\div$ Total liabilities \\
\hline GDP growth rate [GDP] & GDP growth rate per year \\
\hline
\end{tabular}


The data analysis is done through Stata/MP 14.0 software. The delineation of the model estimation is as follows:

$$
\begin{gathered}
F P_{i, t}=\beta_{0}+\beta_{1} C C C_{i t}+\beta_{3} S I Z E_{i t}+\beta_{4} S A L E_{i t}+\beta_{5} L V R G_{i t}+\beta_{6} C A R_{i t}+\beta_{7} C L R_{i t} \\
+\beta_{8} G D P R_{i t}+\eta_{i}+v_{i t}
\end{gathered}
$$

Notes: FP = Measurement of firms' profitability (i.e. accounting firm measurement: return on assets and market firm measurement: Tobin's Q); CCC = Cash Conversion Cycle; SIZE = Firm Size; SALE = sales growth; $L V R G=$ Financial Leverage $; C A R=$ current assets ratio $;$ CLR = current liabilities ratio $; G D P$ $=$ annual GDP growth; $i=$ firm; $t=$ time; the measurement errors components are $v=$ individual error component (a particular characteristics of each firm), and $\eta_{i}=$ unobserved time-invariant firm-specific effect.

\section{Empirical Analysis}

\section{Descriptive Statistics}

Table 2 demonstrates the descriptive analysis of the criterion variables and regressors for total of 720 observations. The average ROA and Tobin's Q for the property industry is $3.094 \%$ and 0.751 respectively. The mean for WCM estimator, CCC is 250.8 days with the DIO, DSO and DPO are equivalent 465.4 days, 157.1 days and 371.7 days proportionately. The annual sales growth rate is comparably high (i.e. $32.15 \%$ ) and average financial leverage is 1.974 , indicating mean value of $97.4 \%$ of debts are utilised in their capital structure. Meanwhile, current assets and current liabilities comprise of $49.74 \%$ and $39.08 \%$ out of total assets owned by firms.

\section{Table 2 Summary Statistics}

\begin{tabular}{lccc}
\hline Variables & Observations & Mean & Standard deviation \\
\hline ROA & 720 & 3.0941 & 5.46 \\
\hline TOBINS'Q & 720 & 0.7515 & 0.29 \\
\hline CCC & 720 & 250.82 & 5573.47 \\
\hline SIZE & 720 & 18.76 & 1.21 \\
\hline SALES & 720 & 32.15 & 193.02 \\
\hline LVRG & 720 & 1.974 & 1.08 \\
\hline CATA & 720 & 49.74 & 20.50 \\
\hline CLTA & 720 & 39.08 & 53.04 \\
\hline GDP & 720 & 0.046 & 0.03 \\
\hline SOurce: Autho & & &
\end{tabular}

Source: Author

\section{Correlation Analysis}

The degree of association between the variables is expounded in table 3 . The results demonstrate negative insignificant linkage between CCC and both of the firm performance indicators (i.e. ROA \& Tobin's Q). This inversed relationship with both accounting and market firm performance indicators, signifying that rapid in trading of properties as well quickening collection period, and deferring disbursement to suppliers would imply positive effect on firms' profitability (Lee, Har, Yow, Lee, \& Sim, 2016). Findings designate absence of multicollinearity issues as the correlation are 
comparatively low (i.e. not exceeding 0.80) (Gujarati, 1995). Moreover, the range of VIF is $1.24-1.28$ validating the absence of multicollinearity in the sample as it is lower than the general accepted threshold of 10.0 (Hair, Black, Babin, Anderson, \& Tatham, 2014).

Table 3 Spearman's Rank Correlation Matric

\begin{tabular}{|c|c|c|c|c|c|c|c|c|c|}
\hline & ROA & $\begin{array}{c}\text { TOBIN'S } \\
\text { Q }\end{array}$ & $\mathrm{CCC}$ & SIZE & SALES & LVRG & CATA & CLTA & GDP \\
\hline ROA & 1.000 & & & & & & & & \\
\hline $\begin{array}{l}\text { TOBIN'S } \\
\text { Q }\end{array}$ & & 1.000 & & & & & & & \\
\hline $\mathrm{CCC}$ & -0.0186 & -0.0558 & 1.0000 & & & & & & \\
\hline SIZE & $\begin{array}{c}0.3005 \\
* * *\end{array}$ & $\begin{array}{c}0.2048 \\
* * *\end{array}$ & $\begin{array}{c}- \\
0.1107 \\
* * *\end{array}$ & 1.0000 & & & & & \\
\hline SALES & 0.0081 & 0.0281 & $\begin{array}{c}- \\
0.0058\end{array}$ & 0.0147 & 1.0000 & & & & \\
\hline LVRG & $\begin{array}{c}-0.1926 \\
* * *\end{array}$ & $\begin{array}{c}0.2680 \\
* * *\end{array}$ & $\begin{array}{c}- \\
0.0319\end{array}$ & $\begin{array}{c}0.1750 \\
* * *\end{array}$ & 0.1219 & 1.0000 & & & \\
\hline CATA & $\begin{array}{c}0.0846 \\
* * *\end{array}$ & $\begin{array}{c}0.1157 \\
* * *\end{array}$ & $\begin{array}{c}0.0937 \\
* * *\end{array}$ & 0.0024 & 0.0515 & 0.0149 & 1.000 & & \\
\hline CLTA & $\begin{array}{c}-0.1806 \\
* * *\end{array}$ & $\begin{array}{c}0.1390 \\
* * *\end{array}$ & $\begin{array}{c}- \\
0.0334\end{array}$ & 0.0295 & 0.0116 & $\begin{array}{c}0.6310 \\
* * *\end{array}$ & $\begin{array}{c}0.1290 \\
* * *\end{array}$ & 1.000 & \\
\hline GDP & $\begin{array}{c}0.0825 \\
* *\end{array}$ & $\begin{array}{c}0.1559 \\
* * *\end{array}$ & $\begin{array}{c}0.0633 \\
* *\end{array}$ & 0.0344 & 0.0223 & $\begin{array}{c}- \\
0.0252\end{array}$ & 0.0307 & $\begin{array}{c}- \\
0.0870 \\
* *\end{array}$ & 1.0000 \\
\hline
\end{tabular}

Notes: $* * *$ Indicates significance at $1 \%$ level $* *$ Indicates significance at $5 \%$ level

Source: Author

\section{Regression Analysis}

The findings of ordinary least square (column 2), fixed effects model (column 3), AHinstrumental variables (column 4), and Arellano-Bond first-differenced GMM analysis with the one-step (column 5 and column 6) are depicted in Table 4 (DV: ROA) and Table 5 (DV: Tobin's Q). Using ROA as a proxy of firm performance, the firms would deteriorate their level of profitability if they adopt aggressive working capital strategy (i.e. shorten the length of CCC), likewise the finding is contradictory with previous researches (Lyngstadaas \& Berg, 2016; Garcia-Teruel \& Martinez-Solano, 2007). On the contrary, the market firm performance indicator, Tobin's Q implies that investors would value much if firms opt to shortening their length of CCC period in order to enhance total shareholder returns (Lyngstadaas \& Berg, 2016; Garcia-Teruel \& Martinez-Solano, 2007). The sales growth rate is revealed to be insignificantly interrelated with the accounting-based indicator, ROA which is being contradicted with earlier studies (Nazir \& Afza, 2009; Eljelly, 2004; Deloof, 2003) likewise market-based 
indicator, with the possible justification of the demand of final products in property industry is liable to be stimulating by various external antecedents (such as interest rate movement, the degree of rigidity policies set by central bank as well as real disposable income), instead of relying merely on internal firm performance. Whereas GDP annual growth rate is insignificant in contemplating both book- and market-based firm performance indicators.

CATA correlates positive and significant with Tobin's Q for $1^{\text {st }}$ difference GMM, which is consistent with previous empirical studies (Nazir \& Afza, 2009; Lee et al., 2016), which evinces that firms in property industry adopts conservative investment strategy in dealing with their short-term resources, due to sustaining firm's real value through hedging against the inflationary pressures in order to enhance firms' costeffectiveness. Contrariwise, the negative yet insignificant coefficient of CLTA implies that the firms are inclined adopt aggressive financing strategy and preferable to use short-term capital instead long-term funding, whereas it eventually instigates undesirable effect on firm's profitability (Nazir \& Afza, 2009; Lee et al., 2016). Nevertheless, these outcomes are contravene with prior investigations in developed nations (Deloof, 2003; Eljelly, 2004), whereby the conjecture may deem Malaysia as a developing country which in the midst of emergent of the financial market infrastructure (Padachi \& Howorth, 2014; Wasiuzzaman, 2015).

Table 4 Estimation of the Model Specification for ROA

\begin{tabular}{|c|c|c|c|c|c|}
\hline & OLS levels & Within groups & 2SLS DIF & GMM DIF & GMM DIF \\
\hline ROA & $\begin{array}{l}0.479 * \\
(0.059)\end{array}$ & $\begin{array}{l}0.479 * \\
(0.059)\end{array}$ & $\begin{array}{c}0.3483 * * * \\
(0.101)\end{array}$ & $\begin{array}{l}0.358^{*} \\
(0.100)\end{array}$ & $\begin{array}{l}0.359 * \\
(0.080)\end{array}$ \\
\hline $\mathrm{ROA}_{\mathrm{t}-1}$ & $\begin{array}{c}0.3976 * * * \\
(0.0613)\end{array}$ & $\begin{array}{c}0.3976 * * * \\
(0.0613)\end{array}$ & $\begin{array}{c}0.3454 * * * \\
(0.0960)\end{array}$ & $\begin{array}{l}0.4232 * * * \\
(0.1406)\end{array}$ & $\begin{array}{l}0.2743 * * \\
(0.1047)\end{array}$ \\
\hline $\mathrm{CCC}$ & $\begin{array}{c}-0.0002 * * * \\
(0.0000)\end{array}$ & $\begin{array}{c}-0.0002 * * * \\
(0.0000)\end{array}$ & $\begin{array}{c}-0.0005^{* * *} * \\
(0.0001)\end{array}$ & $\begin{array}{c}0.0033 \\
(0.0046)\end{array}$ & $\begin{array}{c}0.0003 \\
(0.0008)\end{array}$ \\
\hline SIZE & $\begin{array}{c}0.8112 * * * \\
(0.1746)\end{array}$ & $\begin{array}{c}0.8813 * * * \\
(0.1746) \\
\end{array}$ & $\begin{array}{c}0.0641 \\
(0.1749) \\
\end{array}$ & $\begin{array}{l}-3.3637 \\
(11.6371)\end{array}$ & $\begin{array}{r}2.9815 \\
(2.9087) \\
\end{array}$ \\
\hline SALES & $\begin{array}{c}0.0009 \\
(0.0013) \\
\end{array}$ & $\begin{array}{c}0.0010 \\
(0.0013) \\
\end{array}$ & $\begin{array}{c}0.0021 \\
(0.0018) \\
\end{array}$ & $\begin{array}{l}-0.0014 \\
(0.0156) \\
\end{array}$ & $\begin{array}{c}0.0034 \\
(0.0047) \\
\end{array}$ \\
\hline LVRG & $\begin{array}{c}-0.7173 * * \\
(0.3247)\end{array}$ & $\begin{array}{c}-0.7173 * * \\
(0.3247)\end{array}$ & $\begin{array}{c}0.1750 \\
(0.2067)\end{array}$ & $\begin{array}{l}-6.9329 \\
(7.2717)\end{array}$ & $\begin{array}{c}-4.281 \\
(2.9750)\end{array}$ \\
\hline CATA & $\begin{array}{c}0.0189 * * \\
(0.0089)\end{array}$ & $\begin{array}{c}0.0189 * * \\
(0.0089)\end{array}$ & $\begin{array}{c}0.0113 \\
(0.0084) \\
\end{array}$ & $\begin{array}{l}0.1134 \\
(0.3808)\end{array}$ & $\begin{array}{c}0.0513 \\
(0.0934) \\
\end{array}$ \\
\hline CLTA & $\begin{array}{l}-0.0019 \\
(0.0057) \\
\end{array}$ & $\begin{array}{l}-0.0019 \\
(0.0057)\end{array}$ & $\begin{array}{l}-0.0033 \\
(0.0040) \\
\end{array}$ & $\begin{array}{l}0.1029 \\
(0.1184)\end{array}$ & $\begin{array}{c}0.0709 \\
(0.0772) \\
\end{array}$ \\
\hline GDP & $\begin{array}{c}-93.657 \\
(68.5026) \\
\end{array}$ & $\begin{array}{l}-96.2960 \\
(68.5026) \\
\end{array}$ & omitted & omitted & Omitted \\
\hline $\begin{array}{l}\text { No. of } \\
\text { observation }\end{array}$ & 648 & 648 & 576 & 576 & 576 \\
\hline $\begin{array}{l}\mathrm{m} 1 \\
\mathrm{~m} 2 \\
\text { Sargan } \\
\text { Instruments }\end{array}$ & $\begin{array}{c}-1.40 \\
1.44\end{array}$ & $\begin{array}{l}-0.86 \\
-2.98\end{array}$ & $\begin{array}{c}-4.73 \\
-0.34 \\
R O A_{t-2}\end{array}$ & $\begin{array}{c}-3.65 \\
-0.60 \\
0.3025 \\
R O A_{t-2} \\
R O A_{t-3}\end{array}$ & $\begin{array}{c}-3.61 \\
-1.39 \\
0.027 \\
R O A_{t-2} \\
R O A_{t-3} \\
: \\
R O A_{1} \\
\end{array}$ \\
\hline
\end{tabular}

Source: Author 
Table 5 Estimation of the Model Specification for Tobin's $Q$

\begin{tabular}{|c|c|c|c|c|c|}
\hline & OLS levels & Within groups & 2SLS DIF & GMM DIF & GMM DIF \\
\hline Tobin's Q & $\begin{array}{c}0.664 * * \\
(0.033)\end{array}$ & $\begin{array}{c}0.664 * * * \\
(0.033)\end{array}$ & $\begin{array}{l}0.330^{*} \\
(0.082)\end{array}$ & $\begin{array}{l}0.407 * \\
(0.058) \\
\end{array}$ & $\begin{array}{l}0.454 * \\
(0.056)\end{array}$ \\
\hline Tobin'sQ $\mathrm{Q}_{\mathrm{t}-1}$ & $\begin{array}{c}0.6308 * * * \\
(0.0340)\end{array}$ & $\begin{array}{l}0.6308^{* * *} \\
(0.03404)\end{array}$ & $\begin{array}{c}0.3216^{* * * *} \\
(0.0861)\end{array}$ & $\begin{array}{c}0.2357 \\
(0.1682)\end{array}$ & $\begin{array}{c}0.3991 * * * \\
(0.1021)\end{array}$ \\
\hline $\mathrm{CCC}$ & $\begin{array}{c}0.0120 \\
(0.0006)\end{array}$ & $\begin{array}{l}0.01200 \\
(0.0006)\end{array}$ & $\begin{array}{l}-0.0010 * \\
(0.0007)\end{array}$ & $\begin{array}{c}0.0017 \\
(0.0037)\end{array}$ & $\begin{array}{c}-0.00004 \\
(0.000005)\end{array}$ \\
\hline SIZE & $\begin{array}{c}0.0016 \\
(0.0078) \\
\end{array}$ & $\begin{array}{c}0.0016 \\
(0.0078) \\
\end{array}$ & $\begin{array}{l}-0.0073 * \\
(0.0051) \\
\end{array}$ & $\begin{array}{c}-0.1078 \\
(0.1754) \\
\end{array}$ & $\begin{array}{l}-0.0026 \\
(0.0740) \\
\end{array}$ \\
\hline SALES & $\begin{array}{l}-0.0006 \\
(0.0000) \\
\end{array}$ & $\begin{array}{l}-0.0006 \\
(0.0000)\end{array}$ & $\begin{array}{c}-0.00004 \\
(0.00004) \\
\end{array}$ & $\begin{array}{c}0.0001 \\
(0.0003) \\
\end{array}$ & $\begin{array}{c}0.0004 \\
(0.00009) \\
\end{array}$ \\
\hline LVRG & $\begin{array}{c}0.0290 * * * \\
(0.0097)\end{array}$ & $\begin{array}{c}0.0290 * * * \\
(0.0097)\end{array}$ & $\begin{array}{c}0.0116 \\
(0.0117)\end{array}$ & $\begin{array}{c}0.2649 \\
(0.2565)\end{array}$ & $\begin{array}{c}0.1429 \\
(0.1304)\end{array}$ \\
\hline CATA & $\begin{array}{c}0.0004 \\
(0.0003)\end{array}$ & $\begin{array}{l}0.0004 * \\
(0.0003)\end{array}$ & $\begin{array}{c}0.0002 \\
(0.0003) \\
\end{array}$ & $\begin{array}{c}0.0153 \\
(0.0155) \\
\end{array}$ & $\begin{array}{l}0.0107 * \\
(0.0059) \\
\end{array}$ \\
\hline CLTA & $\begin{array}{l}-0.0000 \\
(0.0002)\end{array}$ & $\begin{array}{c}-0.0000 * * * \\
(0.0002)\end{array}$ & $\begin{array}{l}-0.0002 \\
(0.0002)\end{array}$ & $\begin{array}{c}0.0030 \\
(0.0073)\end{array}$ & $\begin{array}{l}-0.0011 \\
(0.0020)\end{array}$ \\
\hline GDP & $\begin{array}{l}13.5696 \\
(2.6050)\end{array}$ & omitted & omitted & Omitted & omitted \\
\hline $\begin{array}{l}\text { No. of } \\
\text { observations }\end{array}$ & 648 & 648 & 576 & 576 & 576 \\
\hline $\mathrm{m} 1$ & -0.04 & -0.09 & -3.51 & -3.67 & -3.61 \\
\hline $\mathrm{m} 2$ & 1.76 & -0.46 & -0.34 & -0.22 & -0.17 \\
\hline Sargan & & & & 0.684 & 0.753 \\
\hline Instruments & & & $\operatorname{Tobin}^{\prime} s Q_{t-2}$ & $\begin{array}{l}\text { Tobin' }^{\prime} Q_{t-2} \\
\text { Tobin' }^{\prime} Q_{t-3}\end{array}$ & $\begin{array}{c}\text { Tobin's }_{t-2} \\
\text { Tobin's }_{t-3} \\
: \\
\text { Tobin's }^{\prime} Q_{1}\end{array}$ \\
\hline
\end{tabular}

Notes: Year dummies included in all models. Asymptotic standard errors in parentheses. $\mathrm{m} 1$ and $\mathrm{m} 2$ are test for first-order and second-order serial correlation, asymptotically $\mathrm{N}(0,1)$. These test the levels residuals for OLS levels, and the first-differenced residuals in all other columns. GMM results are onestep estimates with heteroschedasticity-consistent standard errors and test statistics. Sargan is a test of the overidentifying restrictions for the GMM estimators, asymptotically $\mathrm{X}_{2}$. P-value is reported. This test uses the minimised value of the corresponding two-step GMM estimators.

$* * *$ Indicates significance at $1 \%$ level

** Indicates significance at 5\% level

* Indicates significance at $10 \%$

Source: Author

\section{Conclusion}

The purpose of this study is to provide empirical evidence for the linkage between working capital management and firm performance for 72 Malaysian public listed firms in the property economy sector for the period of years 2007-2016. This study uses two model specifications in order to test the inferential hypotheses, using accounting-based firm profitability measurement, return on assets (ROA) and market-based firm performance indicator, Tobin's Q coupled with WCM estimator (i.e. CCC) and other control variables to restrict the likelihood of their domination on the performance of the firms. The researcher applies a panel data and employ the GMM method of estimation 
to run data analysis, which is extensively adopted to control for unobserved heterogeneity and to cater for possible endogeneity issues. The results of ROA showing a insignificant positive relationship with WCM, indicating a contradiction with previous empirical proofs, which further implying the requirements to manage working capital is dispersed across different industry sector (Gill et al., 2010; Lyroudi \& Lazaridis, 2000). Nevertheless, Tobin's Q demonstrates insignificant negative interrelation with CCC, which confirming the outcomes of previous empirical investigations.

This research outcomes intend to put forward marked of policy implications for the finance managers and imminent investors in the emerging financial market such as Malaysia. Firms with more aggressive investment policy as well as conservative financing policy towards short-term resources and liabilities are more likely to produce more returns. This study found there is indifferent results for both firm performance indicators. Concerning the uniqueness of property industry, the investors deem the firms that utilising a greater extent of long-term sources of capital e.g. equity and long-term bonds to performed better than the opposite ones. Nonetheless, there are variety of antecedents such as ownership structure and agency issues might be worth to be explore in the prospective studies.

\section{References}

Afrifa, G. A. (2013). Working capital management and AIM listed SME companies profitability: a mixed research method approach. Unpublished $\mathrm{PhD}$ dissertation, Bournemouth University, Bournemouth.

Afrifa, G. A. \& Padachi, K. (2016). Working capital level influence on SME profitability. Journal of Small Business and Enterprise Development, 23(1), 44-63.

Almeida, J. R. \& Eid, Jr. W. (2014). Access to finance, working capital management and company value: evidence from Brazilian companies listed on BM\&FBOVESPA. Journal of Business Research, 67(2014), 924-934.

Arellano, M. \& Bond, S. (1991). Some test of specification for panel data: Monte Carlo evidence and an application to employment equations. Review of Economic Studies, 58(2), 277-297.

Atanasova, C. (2008). Access to institutional finance and the use of trade credit. Financial Management, 36(1), 49-67.

Baltagi, B. H. (2005). Econometric analysis of panel data. ( $3^{\text {rd }}$ ed.). England: John Wiley and Sons Ltd.

Bandara, R. M. S. (2015). Impact of working capital management policy on market value addition. Global Journal of Contemporary Research in Accounting, Auditing and Business Ethics, 1(2), 354-373.

Baños-Caballero, S., García-Teruel, P. J., \& Martínez-Solano, P. (2014). Working capital management, corporate performance, and financial constraints. Journal of Business Research, 67(3), 332-338.

Bhatia, S. \& Srivastava, A. (2016). Working capital management and firm performance in emerging economies: evidence from India. Management and Labour Studies, 41(2), 1-17.

Bursa Malaysia. (2019). Main market: listing requirements. Chapter 2: general, 13 March 2019. Bursa Malaysia Berhad, Malaysia. Retrieved from 
http://www.bursamalaysia.com/market/regulation/rules/listingrequirements/main-market/listing-requirements.

Darun, M. R., Roudaki, J., \& Radford, J. (2015). The evolution of working capital management research. International Business Management, 9(5), 987-997.

Deloof, M. (2003). Does working capital management affect profitability of Belgian firms? Journal of Business Finance \& Accounting, 30(4), 573-587.

Eljelly, A. M. A. (2004). Liquidity profitability trade off: an empirical investigation in an emerging market. International Journal of Commerce and Management, 14(2), 48-61.

Ferlito, C. (2018). Affordable housing and cyclical fluctuations: the Malaysian property market. Policy Ideas, No 51. IDEAS Policy Research Bhd, Kuala Lumpur, Malaysia. Retrieved from http://www.ideas.org.my/wpcontent/uploads/2018/07/P151-AffordableHomes.pdf

Garcia-Teruel, P. J. \& Martinez-Solano, P. (2007). Effects of working capital management on SME profitability. International Journal of Managerial Finance, 3(2), 164-177.

Gentry, J., Vaidyanathan, R., \& Lee, H. (1990). A weighted cash conversion cycle. Financial Management, 19(1), 90-99.

Gill, A., Biger, N., \& Mathur, N. (2010). The relationship between working capital management and profitability: evidence from the United States. Business and Economics Journal, 10(2010), 1-9.

Gilligan, T., Smirlock, M., \& Marshall, W. (1984). Scale and scope economies in the multi-product banking firm. Journal of Monetary Economics, 13(3), 393-405.

Gujarati, D. (1995). Basic economics. Singapore: McGraw-Hill.

Hair, J. F., Black, B., Babin, B., Anderson, R. E., \& Tatham, R. L. (2014). Multivariate data analysis. ( $7^{\text {th }}$ ed.). Harlow, United Kingdom: Pearson Education Limited.

Hsiao, C. (2003). Analysis of panel data. ( $2^{\text {nd }}$ ed.). Cambridge: Cambridge University Press.

Jose, M. L., Lancaster, C., \& Stevens, J. L. (1996). Corporate returns and cash conversion cycles. Journal of Economics and Finance, 20(1), 20-33.

Lee, H. S., Har, W. M., Yow, T. O., Lee, S.Y., \& Sim, K. C. (2016). Does working capital management influence the performance of wholesale and property industry in Malaysia? International Journal of Economics and Management Systems, 1(2016), 1-14.

Losbichler, H. \& Mahmoodi, F. (2012). Why working capital should matter to you? Supply Chain Management Review, 16(6), 26-33.

Lyngstadaas, H. \& Berg, T. (2016). Working capital management: evident from Norway. International Journal of Managerial Finance, 12(3), 295-313.

Lyroudi, K. \& Lazaridis, Y. (2000). The cash conversion cycle and liquidity analysis of the food industry in Greece. SSRN Electronic Journal, 1-32. doi: $10.2139 /$ ssrn. 236175

Kamal, R. (2013). Can Morningstar analyst ratings predict fund performance? The Journal of Applied Business Research, 29(6), 1665-1672.

Kaur, J. (2010). Working capital management in India Tyre industry. International Research Journal of Finance Economics, 46(2010), 7-15.

Kwenda, F. \& Holden, M. (2014). Determinants of working capital investment in South Africa: evidence from selected JSE-listed firms. Journal of Economics and Behavioural Studies, 6(7), 569-580. 
Madishetti, S. \& Kibona, D. (2013). Impact of receivables and payables management on the profitability of SMEs in Tanzania. Journal of Economics and Management, 2(3).

Makori, D. M. \& Jagongo, A. (2013). Working capital management and firm profitability: empirical evidence from manufacturing and construction firms listed on Nairobi Securities Exchange, Kenya. International Journal of Accounting and Taxation, 1(1), 1-14.

Mansoori, E. \& Muhammad, J. (2012). The effect of working capital management on firm's profitability: Evidence from Singapore. Interdisciplinary Journal of Contemporary Research Business, 4(5), 472-486.

Mathuva, D. M. (2010). The influence of working capital management components on corporate profitability: a survey on Kenyan listed firms. Research Journal of Business Management, 4(1), 1-11.

Moss, J. \& Stine, B. (1993). Cash conversion cycle and firm size: a study of retail firms. Managerial Finance, 19(8), 25-34.

Motlíček, Z. \& Polák, J. (2015). Appropriate determination of net working capital in corporate financial management. Acta Universitatis Agriculturae ET Silviculturae Mendelianae Brunensis, 63(4), 1323-1330.

Nazir, M. S. \& Afza, T. (2009). Impact of aggressive working capital management Policy on firms' profitability. The IUP Journal of Applied Finance, 15(8), 1930 .

Nobanee, H., Abdullatif, M., \& AlHajjar, M. (2011). Cash conversion cycle and firm's performance of Japanese firms. Asian Review of Accounting, 19(2), 147-156.

Padachi, K. \& Howorth, C. (2014). Focus on working capital management practices among Mauritian SMEs: survey evidence and empirical analysis. Journal of Business Management and Economics, 5(4), 97-108.

Palombini, N. V. N. \& Nakamura, W. T. (2011). Key factors in working capital management in the Brazilian market. Rev. Adm. Empress, 52(1), 55-69.

Pass, C. L. \& Pike, R. H. (1984). An overview of working capital: a neglected subject. Management Decision, 25 (1), 18-24.

Petersen, M. A. \& Rajan, R. G. (1997). Trade credit: theories and evidence. Review of Financial Studies, 10(3), 661-691.

PWC (2017). Cash for growth: 2017 Malaysia working capital study. Retrieved February 20, 2018 from http://www.pwc.com.my

Raheman, A. \& Nasr, M. (2007). Working capital management and profitability - case of Pakistani firms. International Review of Business Research Papers, 3(1), 279300.

Richards, V. D. \& Laughlin, E. J. (1980). A cash conversion cycle approach to liquidity analysis. Financial Management, 9(1), 32-38.

Roodman, D. (2009). How to do xtabond2: an introduction to difference and system GMM in Stata. The Stata Journal, 9(1), 86-136.

Ross, S. A., Westerfield, R. W., \& Jordan, B. D. (2010). Fundamentals of Corporate Finance. (9th e.d.). New York: McGraw-Hill/Irwin.

Sartoris, W. L. \& Hill, N. C. (1983). Cash and working capital management. The Journal of Finance, XXXVIII (2), 349-360.

Shin, H. \& Soenen, L. (1998). Efficiency of working capital management and corporate profitability. Finance Practice and Education, 8(2), 37-45. 
Singh, H. P. \& Kumar, S. (2014). Working capital management: a literature review and research agenda. Qualitative Research in Financial Markets, 6(2), 173-197.

Smith, J. K. (1987). Trade credit and informational asymmetry. The Journal of Finance, 42(4), 863-872.

Tauringana, V. \& Afrifa, G. A. (2013). The relative importance of working capital management and its components to SMEs' profitability. Journal of Small Business and Enterprise Development, 20(3), 453-469.

Ukaegbu, B. (2014). The significant of working capital management in determining firm profitability: evidence from developing economies in Africa. Research in International Business and Finance, 31(2014), 1-16.

Wasiuzzaman, S. (2015). Working capital and firm value in an emerging market. International Journal of Managerial Finance, 11(1), 60-79.

Zariyawati, M. A., Annuar, M. N., Taufiq, H., \& Abdul Rahim, A. S. (2009). Working capital management and corporate performance: case of Malaysia. Journal of Modern Accounting and Auditing, 5(11), 47-54. 